\title{
Management Perubahan Sebagai Upaya Peningkatan Daya Saing Perusahaan Menggunakan Analisis Balance Score Card
}

\author{
Endang Wahyudi'), Hasanudin ${ }^{2)}$, Lydia Salvina Helling ${ }^{3)}$, A.A Gede Ajusta ${ }^{4)}$ \\ Universitas Bina Sarana Informatika \\ Email: ${ }^{1}$ endang.edw@bsi.ac.id, ${ }^{2}$ hasanudin.hnu@bsi.ac.id, ${ }^{3}$ Lydia.lsh@bsi.ac.id, \\ ${ }^{4}$ a.gede.age@bsi.ac.id
}

\begin{abstract}
Abstrak
Manajemen Perubahan bertujuan untuk mengontrol resiko dan meminimalisasi efek kerugian yang mungkin terjadi pada perusahaan, perubahan manajemen dengan pendekatan kemanusiaan memberikan efek terbaik. Balance Score Card merupakan suatu alat untuk melihat pandangan / Persfektif terhadap pengukuran kinerja dari perusahaan, terdapat empat perspektif yaitu financial, internal process, Learning \& Grow dan Customer, Sasaran Manajemen Perubahan adalah untuk menetapkan prosedur standar pengelolaan permintaan perubahan secara tangkas dan efisien dalam upaya meminimalkan risiko dan dampak perubahan yang dapat terjadi secara drastis terhadap operasi bisnis, faktor pendorong perubahan berdasarkan kepentingan top management atau permasalahan operasional harian dari staf pelaksana system diantaranya permasalahan tentang kesulitan agen untuk closing, tagihan tak terbayarkan dari pengembang, lambatnya pencairan fee menjadi fokus dari strategi change management sehingga menerbitkan strategi upgrading system dan Pengelolaan Training agen melalui Jpi Incubator ( J.inc) serta membentuk selling validator.
\end{abstract}

Kata Kunci: Manajemen Perubahan, Balance Score Card, JPI Incubator

\section{PENDAHULUAN}

Startegi perusahaan dalam menjalankan usahanya tidak dapat lepas dari usaha untuk memuaskan pelanggannya, membentuk posisi pasar yang menarik dan mencapai sasaran organisasi sehingga memerlukan beberapa kumpulan alternatif atau pilihan atas suatu cara untuk mencapai tujuan.
Dalam persaingan agen properti diperlukan suatu usaha yang bersifat inovatif sehingga perusahaan dapat tetap berjalan dengan baik. Usaha tersebut tentu harus disesuaikan dengan resources yang ada.

PT. Jaya Persada Indonesia atau JPI merupakan perusahaan yang didirikan dengan semangat kebersamaan, melihat peluang terhadap perkembangan properti dan sumber daya manusia yang dimiliki, maka perusahaan saat ini menitik beratkan area 
bisnis yang dikerjakan oleh PT. Jaya Persada Indonesia adalah Developer Property, Keagenan Properti (JPI Propertindo) serta area bisnis lainnya, seperti konsultan IT. Prioritas kegiatan yang diutamakan saat ini adalah keagenan property hal ini disebabkan kegiatan keagenan property membutuhkan kemampuan sales dengan biaya terjangkau namum memberikan hasil yang signifikan.

Untuk menunjang kegiatan perusahaan dalam aktifitas sehari-hari yang meliputi kegiatan property seperti listing, canvasing, training agen, rectruitmen, selling maka diperlukan suatu sistem yang dapat membantu, kegiatan tersebut.

Berdasarkan perjalanan perusahaan dalam 5 tahun ini maka ditemukan beberapa kondisi yang harus diperbaiki seperti terlambatnya pencairan fee agen, kurang terkontrolnya tagihan developer yang tertunda, kesulitan agen untuk closing perbulan.

Analisis Balance score card melihat permasalahan perusahaan dalam 4 persfektif yaitu; Financial, Learning \& Grow, Internal Proses dan Customer. Sehingga diharapkan dengan metode analisis ini ditemukan solusi optimal.

Oleh karena itu kami tertarik untuk mengetahui strategi perubahan yang dilakukan perusahaan ini dalam jurnal ini yang diberi judul "Management Perubahan Sebagai Upaya Peningkatan Daya Saing Perusahaan Menggunakan Analisis Balance Score Card".

\section{METODOLOGI PENELITIAN}

Untuk mendukung hasil analisa terhadap kemungkinan adanya manajemen perubahaan pada perusahaan maka diperlukan nya suatu tools yang digunakan seperti wawancara, kuisioner, data pendukung yang didapat pada website rumahniaga.com, serta Balance Score Card.

Menurut Orr Anthony Beberapa manfaat yang dapat dihasilkan dari Change Management termasuk:

- Peningkatan keselarasan TI ke bisnis

- Mengurangi dampak buruk pada operasi bisnis

- Peningkatan visibilitas ke perubahan IT

- Responsif yang diprioritaskan untuk berubah

- Peningkatan manajemen risiko

- Mengurangi gangguan layanan dan downtime sistem

- Meningkatkan produktivitas staf

- Implementasi perubahan lebih cepat 
Jenis-jenis Perubahan

1) Perubahan Darurat / Mendesak

Perubahan darurat adalah sesuatu yang harus dinilai dan diimplementasikan secepat mungkin untuk menyelesaikan insiden besar. Perubahan darurat cenderung lebih mengganggu dan memiliki tingkat kegagalan yang tinggi, sehingga harus dijaga agar tetap minimum. Definisi pasti dari perubahan darurat harus didefinisikan dalam kebijakan manajemen perubahan.

\section{2) Perubahan Standar}

Perubahan standar adalah perubahan yang sering terjadi, berisiko rendah dan memiliki prosedur yang telah ditetapkan sebelumnya dengan tugas yang didokumentasi kan untuk diselesaikan. Perubahan standar tunduk pada persetujuan awal untuk mempercepat proses manajemen perubahan. Change Model (rencana terdokumentasi dan berulang untuk mengelola jenis perubahan tertentu) yang menggambarkan proses untuk menangani perubahan berulang sering kali dibuat untuk perubahan standar. Jika jenis perubahan standar meningkatkan risiko bagi organisasi, itu mungkin menjadi Perubahan Normal.

3) Perubahan Besar
Perubahan yang mungkin memiliki implikasi keuangan yang signifikan dan / atau berisiko tinggi. Perubahan seperti itu membutuhkan proposal perubahan mendalam dengan justifikasi keuangan dan tingkat persetujuan manajemen yang sesuai. Setiap proses organisasi untuk mengidentifikasi dan mengelola perubahan besar akan berbeda tergantung pada ukuran dan kompleksitas bisnis. Suatu perubahan dalam hal ini dapat berubah dari yang operasional menjadi taktis, atau taktis menjadi strategis dan memerlukan tingkat otoritas yang berbeda untuk persetujuan.

4) Perubahan Normal

Perubahan normal adalah perubahan yang tidak standar dan tidak darurat dan biasanya memerlukan perubahan penting untuk layanan atau infrastruktur TI. Perubahan normal tunduk pada proses peninjauan manajemen perubahan penuh, termasuk peninjauan oleh Change Advisory Board (CAB) dan otorisasi / penolakan.

Balance Score Card merupakan tools yang digunakan untuk melihat hasil kerja perusahaan secara holistik dan manajemen mengetahui sejauh mana perkembangan perusahaan yang telah dicapai saat ini, perubahan strategi menggunakan analisis ini memerlukan informasi yang akurat. 
Dalam BSC terdapat 4 jenis persfektif yang digunakan untuk mengukur kinerja perusahaan yaitu

Financial , Dalam persfektif ini management Cash Flow mendapatkan perhatian khusus, hal ini disebabkan agar perusahaan dapat melakukan tindakan penurunan biaya dan optimalisasi dari peluang pendapatan derifikasi product. Ada tiga tolok ukur yaitu :

a. Pertumbuhan dari pertambahan yang didapat selama proses bisnis berlangsung

b. Penurunan aset kearah yang optimal dan memaksimalkan strategi investasi

c.Penurunan biaya dan meningkatnya produktifitas kerja

Internal Proses, Dalam persfektif ini perusahaan menilai seberapa besar kepatuhan karyawan terhadap aturan atau SOP yang telah ditentukan serta sinergi dari setiap unit kerja. Untuk mengukur poin ini, Direksi perusahaan harus rutin mengamati bagaimana kondisi internal dalam perusahaan. Apakah semuanya dijalankan sesuai dengan metode yang ditetapkan atau malah keluar dari peraturan. Kemampuan dan keahlian yang dimiliki setiap karyawan akan menghasilkan proses bisnis internal yang bagus. Selain bertambahnya jumlah konsumen, omzet dan keuntungan yang didapat perusahaan juga akan bertambah, ada tiga hal yang dapat diperhatikan dalam Persfektif ini yaitu :

a. Proses inovasi terkait dengan ide terhadap produksi / flayer iklan/ media promosi yang di gunakan

b. Proses operasi terkait dengan aktivitas harian bagian internal perusahaan apakah sudah sesuai dengan Key Performance Indicator (KPI) masing masing unit kerja

c. Proses pasca penjualan terkait dengan metode pemasaran

Customer, Persfektif ini berkaitan dengan cara perusahaan melayani dan memahami keperluan atau kebutuhan konsumen, pelayanan yang baik menentukan tingkat kepuasan konsumen yang berakibat repeated order.

Learning \& Growth, Karyawan merupakan aset penting bagi perusahaan karena tanpa keberadaan karyawan proses pertumbuhan dan perkembangan perusahaan akan mendapatkan hambatan yang berarti serta dapat tidak terpenuhinya 3 persfektif lainnya yaitu financial, pelanggan, internal proses, terdapat tiga hal yang dapat diperhatikan dalam persfektif ini yaitu :
a. Kemampuan karyawan / skill 
b. Kemampuan mengelola informasi

c. Motivasi, dorongan dan tanggung jawab

Menurut Saputra Hidayat (2019)

Balanced Scorecard (BSC) adalah sistem manajemen yang bertujuan untuk menerjemahkan goals organisasi kedalam serangkaian program kerja, selanjutnya program kerja tersebut akan diukur, dipantau atau dirubah untuk memastikan bahwa goals organisasi terpenuhi.

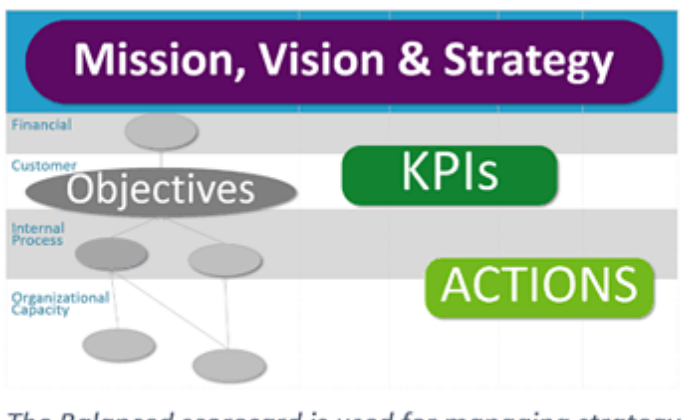

Gambar 1. Pengelolaan strategi manajemen menggunakan balance score card

Berdasarkan gambar 1, balance score card dapat digunakan untuk mengelola strategi bisnis perusahaan yang ditetapkan management dalam visi, misi serta strategi. Objektifitas yang dilakukan fokus kepada customer satisfaction dengan harapan meningkatnya satisfaction maka revenue dan repeated order dari customer dapat terpenuhi sehingga cash flow perusahaan berada dalam keadaan baik, maka pembenahan internal proses wajib dilakukan untuk menentukan proses mana yang inefisiensi dan yang harus ditingkatkan kualitasnya dengan cara meningkatkan IT support, membangun culture positif ( SOP yang jelas, Reward dan Punishment sesuai dengan kinerja unit ) untuk meningkatkan organizational capacity

\section{HASIL DAN PEMBAHASAN DENGAN ANALISA BALANCE SCORE CARD.}

Change management merupakan suatu cara bagi management untuk mengukur sejauh mana di perlukannya perubahan terhadap suatu proses / prosedur sistem yang sudah berjalan selama ini. Beberapa kondisi yang ada pada perusahaan :

- Divisi Keuangan lambat mengetahui developer mana saja yang lambat dalam melakukan pembayaran fee

- Divisi Marketing lambat mengetahui agen mana saja yang sudah closing, melakukan canvasing, melakukan listing produk

- Divisi HRD kesulitan untuk menegetahui agen mana yang perlu diajukan mengikuti training.

- Penurunan Jumlah Closing dalam semester pertama tahun 2019 untuk 
masing masing area sesuai dengan tabel di bawah ini :

$\begin{array}{llllll}\text { Area } & \text { Jan } & \text { Feb } & \text { Mar } & \text { Apr } & \text { Mei } \\ \text { Jakarta } & 1 & 1 & 1 & \text { o } & \text { o } \\ \text { Pusat } & 16 & 5 & 17 & 6 & 18 \\ \text { Timur } & 57 & 32 & 35 & 26 & 35 \\ \text { Selatan } & 79 & 82 & 95 & 97 & 66 \\ \text { Barat } & 3 & 6 & 5 & 4 & 2 \\ \text { Utara } & 15 & 13 & 17 & 15 & 19 \\ \text { Total } & 171 & 139 & 170 & 148 & 140\end{array}$

Tabel 1. Data Closing Smt-1 thn 2019

Analisis Balance score card digunakan managemen untuk melihat secara keseluruhan (Holistik) kondisi yang dialami saat ini sehingga management dapat menentukan perubahan strategi perusahaan. Sangat penting bagi perusahaan untuk mengembang kan strategi bisnis berdasarkan informasi yang akurat sehingga dalam era industri 4.0 ini perusahaan dapat menghadapinya apakah dengan bertahan atau jika diperlukan melakukan diversifikasi usaha.

\section{Balance Score Card memiliki 4} pandangan terhadap kondisi yang dianalisa secara keseluruhan yaitu :

\section{A. Financial ( Keuangan )}

Pandangan ini melihat kinerja perusahaan dari pengelolaan cash flow keuangan apakah sudah tersistem, akurat, anggaran sesuai dengan perencanaan, akuntabilitas dapat dipertanggung jawabkan.
Selama perjalanan kegiatan perusahaan ditemukan beberapa kondisi yang berhubungan dengan keuangan diantaranya :

- Direktur keuangan sulit mengetahui dengan cepat posisi keuangan secara realtime

- Dibutuhkan waktu yang lama untuk membuat rekapitulasi pengeluaran

- Sulit mengetahui detail piutang perusahaan

- Dibutuhkan waktu lama untuk proses pencairan fee agent

Untuk perspeftif ini dilakukan upgrading system keuangan menggunakan accounting system

B. Customer

Pandangan ini melihat bahwa objectivitas strategi yang diharapkan bermuara kepada kepuasan konsumen sehingga layanan kepada konsumen menjadi sasaran dari persfektif ini.

Untuk perusahaan yang memposisikan sebagai market place maka ada 2 jenis konsumen, yaitu Developer atau pengembang yang sudah bermitra untuk menjual properti dan dipasarkan oleh perusahaan, dan Free Agency yang sudah tercatat datanya sebagai agen properti.

Strategi yang digunakan untuk menjaga kepercayaan pengembang dapat dilakukan dengan memperbaki proses administrasi 
kelengkapan dokumen penagihan dengan akurat, dan cepat.

Peningkatan loyalitas agen perlu ditingkat kan sehingga jumlah agen yang closing dapat meningkat, hal ini dapat berimplikasi terhadap kepercayaan pengembang untuk terus menggunakan jasa perusahaan dalam hal marketing properti, untuk persfektif ini dilakukan sarana pelatihan berbentuk incubator yang tersistem, berkesinambungan, materi update serta trainer yang berpengalaman

C. Internal Proses

Pandangan ini melihat hal apa saja yang perlu diperhatikan dalam aktivitas atau kegiatan semua bagian dalam perusahaan, apakah semuanya dikerjakan sesuai dengan jobdesk atau KPI masing masing divisi.

Strategi yang dapat dilakukan perusahaan terkait peningkatan value dalam persfektif ini adalah Membentuk Selling Validator yang memiliki tugas sebagai koordinator dan mediasi antara pelisting dan developer terkait pembayaran fee

\section{Learning \& Growth ( Capacity Organizational)}

Pada Pandangan ini perusahaan dapat melihat kemampuan penjualan / memasarkan produk dari masing masing agen, mengelola informasi produk yang terdapat pada aplikasi maupun website, serta motivasi atau dorongan yang dimiliki agen perusahaan

Berdasarkan data yang dimiliki saat ini terdapat kurang lebih 3.692 agen yang telah dilantik namun jumlah closing baru mencapai $1 \%$ saja, jumlah agen yang melakukan instalasi aplikasi jpi android berkisar 300 agen, kegiatan canvasing diikuti sekitar $3 \%$ dari agen yang dilantik, maka strategi yang digunakan perusahaan yaitu membentuk JPI Incubator yang memiliki tugas untuk meningkatkan performa agen dengan kurikulum update, system training berbasis iso 9001:2008.

\section{KESIMPULAN}

Balance Score Card merupakan suatu tools atau alat yang digunakan perusahaan untuk melihat kondisi menyeluruh, sehingga dalam menentukan perubahan manajemen semuanya terdokumentasi, terarah dan sistematik. Berdasarkan kondisi di atas manajemen melakukan strategi perubahan standard diantaranya adalah :

- Membentuk Selling Validator yang memiliki tugas sebagai koordinator dan mediasi antara pelisting dan developer terkait pembayaran fee

- Membentuk Incubator yang bertugas untuk meningkatkan skill dan 
pengetahuan marketing properti dengan kurikulum pelatihan up to date, mengadopsi standar ISO 9001:2008

- Membuat Training dalam JPI Incubator berdasarkan tingkat skill yaitu tahap Dasar, Tahap Terampil dan Tahap Mahir Demikian ulasan mengenai analisis Manajemen Perubahan menggunakan Balance Score Card PT JPI, semoga dapat berguna bagi kita semua.

\section{DAFTAR PUSTAKA}

Antony, Orr. " How to Move at Digital

Speed While Upholding ITIL

Principles."

https://www.cherwell.com/library/es

sential-guides/essential-guide-to-itil-

change-management/, 2019

Jogiyanto Hartono . “ Sistem Informasi

Startegik untuk keunggulan kompetitif

", Andi Yogyakarta ,2005.
Kotler, Philip. "Marketing Management".Tenth Edition. Prentice Hall New York, 2000.

Prosci, "What is change Management and How Does it Work? ", https://www.prosci.com /resources/articles/the-what-why-andhow-of-change-management , 2019

Spector Jaime, Understanding IT Change Management vs Organizational Change:

https://www.sunviewsoftware.com/blo g/understanding-it-changemanagement-vs.-organizationalchange, 2017

Tim IT, Manual Property Agen, PT Jaya Persada Indonesia, 2016. 